\title{
Influence of Sino - Burmese Oil and Gas Pipeline Construction on Energy Structure in Southwest China
}

\author{
Guiyao Zheng \\ International Business School \\ Yunnan University of Finance and Economics \\ Kunming, China \\ 1139171885@qq.com
}

\author{
Ersi Liu* \\ International Business School \\ Yunnan University of Finance and Economics \\ Kunming, China \\ Liuersi@163.com
}

\begin{abstract}
April 10, 2017, carrying 140,000 tons of crude oil "joint power" successfully berthing Myanmar Buddha Mude Island, and began to unload crude oil, which is a landmark moment, the Sino-Burmese crude oil pipeline project put into operation ! China-Myanmar oil and gas pipeline is China's Kazakhstan, Central Asia, China and Russia after the construction of the fourth largest energy strategic channel, its operation to China to solve energy security issues, to achieve diversification of energy sources and energy transport channel diversification has great strategic significance. At present, the vast majority of China's imports of crude oil is dependent on the Malacca Strait of the sea transport channel into the territory China-Myanmar crude oil pipeline for China's oil and gas imports in the southwest direction opened up an important land channel add an import line for china imports of crude, Is conducive to enhancing China's oil supply security. This paper attempts to introduce the Sino-Burmese oil and gas pipeline project construction overview, analysis of the project in southwest China's energy structure, economic development and other aspects of the impact, And how to make the project play the greatest strategic significance.
\end{abstract}

Keywords-Sino-Burmese oil and gas pipeline; energy structure; regional development

\section{INTRODUCTION}

China-Myanmar oil and gas pipeline is the fourth largest energy strategic channel after China's construction of China's China and Kazakhstan, China and Asia, China and Russia. Its operation has great significance for China to solve energy security problems, it's running on China to solve energy security issues and diversification of energy sources and diversification of energy transport channels are of great strategic significance. Given the significance of the project, Many domestic and foreign scholars for in-depth analysis and demonstration, but there is little research on the impact of this project on the energy structure in the southwest.

For the existing research to sort out, Wang Xiaomei [1] analyzed the main problems of China's energy security, analysis of the import channels for fossil fuel energy and the strategic significance of the Sino-Burmese pipeline
project.Zhang Jian [2] Sino-Burmese pipeline fully embodies the strategic cooperation between China and Myanmar, enhance the relationship between the two countries. Deng Shengpeng [7] detailed analysis of the natural situation in Yunnan Province, as well as the impact of natural gas on the industrial structure, Finally, Yang Lin Industrial Zone as a case for the description. Xue $\mathrm{Li}$ [3] for China's crude oil imports of Malacca dilemma were analyzed, and how our country's response, and effectively overcome the difficulties.

Through access to literature, to grasp the current status of the study of the project, This paper analyzes the energy situation of the Sino-Myanmar oil and gas pipeline project and the analysis of the energy situation in the southwest China, and then analyzes the impact of the project on the energy structure in the southwest region, and finally plays the strategic significance of the project.

\section{SinO-Burmese OIL AND GAS PiPeline Profile}

China-Myanmar oil and gas pipeline is China and Kazakhstan crude oil pipeline, China and Central Asia gas pipeline and Sino-Russian crude oil pipeline after another important energy import channel. It includes crude oil pipelines and natural gas pipelines, it can make the oil transport without the Malacca Strait, from the southwest to China. The origin of the Sino-Burmese crude oil pipeline is located on the west coast of Myanmar's Isle of Man. Natural gas pipeline starting point in Jiao Hong Kong, by Myanmar Rakhine State, Magu province, Mandalay province and Shan State, from Yunnan Ruili in And once was "oil shortage" troubled Chongqing, will become the last stop of crude oil pipeline to China [4], will be in Guizhou Anshun oil and gas pipeline separation, And once was "oil shortage" troubled Chongqing, will become the last stop of crude oil pipeline.

Natural gas pipeline, will be south to reach Guangxi, The pipeline is about 771 kilometers in Myanmar, The total length of crude oil pipeline in China is $1631 \mathrm{~km}$ and the natural gas pipeline is $1727 \mathrm{~km}$ in length. It is expected that this pipeline will deliver 12 billion cubic meters of natural gas to China each year, While the design capacity of crude oil pipeline is 22 million tons per year [5], the oil and natural gas transported to

\footnotetext{
*Corresponding author
} 
China in China's southwestern region of Yunnan Lijiang and Chongqing municipalities to establish an annual output of 10 million tons of matching refineries. The total investment in this project is as high as US \$ 2.54 billion, with oil pipeline investment of US \$ 1.5 billion and natural gas pipeline investment of US \$ 1.04 billion [6].

\section{The Strategic SignificANCE OF SINO-BuRMESE PIPELINE PROJECT}

China has become the world's third largest oil importer, China's oil demand in 2020 is expected to reach 520 million tons, when oil imports will depend on more than $60 \%$. At present, China has exported oil to more than 30 countries. With the sustained and rapid development of China's economy, energy consumption continues to grow, China's energy demand to further highlight the various contradictions: On the one hand the oil import channel is single, More than half from Oman, Iran, Saudi Arabia and other Middle East; on the other hand, Most of the oil transport through the Suez Canal - Indian Ocean - Malacca Strait route, far range and Risky. At present, about four fifths of China's imports of oil are transported through the Malacca Strait.

Malacca Strait is one of the world's sensitive areas, has an important strategic position, the United States for many years will be a must, the current control of the Malacca Strait is the US Pacific Fleet. At the same time, the waters of piracy is also rampant, according to statistics, $60 \%$ of the global piracy attacks have occurred here. Piracy is not only a serious threat to the passage of the ship, but also the loss of goods and personnel, high insurance payments to the relevant countries have caused significant losses. It is based on the "Malacca predicament" concerns [8], China as early as the beginning of this century began to explore the diversification of oil imports, and Sino-Burmese oil and gas pipeline is one of the options to crack the dilemma. China-Myanmar crude oil pipeline for China's oil and gas imports in the southwest direction has opened up an important land channel for China's imports of crude oil added an import line, it is conducive to enhancing China's oil supply security.

Myanmar's natural gas resources are more abundant, proven reserves of about 300 billion cubic meters, Estimated reserves of up to more than 2 trillion cubic meters [9], ranked tenth in the world. The most promising natural gas reserves in Myanmar are located in the "Swiss natural gas field" in the western Arakawa, where the A-1 and A-3 blocks are certified to be more than 9 billion cubic feet of natural gas reserves.

China-Myanmar oil and gas pipeline can not only improve China's energy import safety, but also can make Burma natural gas export diversification, change the long-term dependence on the Thai market situation, increase the Burmese government revenue, the formation of Sino-Burmese win-win situation. Before the opening of China-Myanmar gas pipeline, Thailand is a single export market for natural gas and the largest source of income for the Myanmar government. ChinaMyanmar oil and gas pipelines and related infrastructure, in the next 30 years to bring a total of 300 to 56 billion US dollars to Myanmar's fiscal revenue [10], more than $40 \%$ of the revenue from natural gas exports and pipeline transit fees, this provides the Myanmar government with an important opportunity to reduce excessive reliance on Thailand and increase revenue.

\section{The CURRENT Situation OF ENERGY StRUCTURE IN SOUTHWEST CHINA}

China's southwestern region has long been the lack of large-scale refining base, mainly rely on South China, northwest and other refineries to provide refined oil, long distance, high cost. and in the end of the national supply of refined oil. In the four bottlenecks restricting the development of coal and electricity in the southwest of China, once the problem of oil supply will soon be transmitted to coal, electricity, gas and other resources.

TABle I. Summary of CoAl Resources In Four Provinces AND Cities IN 2013 Unit: 100 MiLLION TON

\begin{tabular}{|c|c|c|}
\hline province & Forecast coal reserves & Proven resource reserves \\
\hline Sichuan & - & 135.3 \\
\hline Chongqing & 30.49 & 23.07 \\
\hline Guizhou & 2400 & 587.27 \\
& & \\
\hline Yunnan & 246.5 & 150 \\
\hline
\end{tabular}

TABLE II. NATURAL RESOURCES OF FOUR PROVINCES AND MUNICIPALITIES IN 2016 UNIT: 100 MILLION CUBIC METERS

\begin{tabular}{|c|c|}
\hline province & Total resources \\
\hline Sichuan & 71851 \\
\hline Chongqing & 3650 \\
\hline Guizhou & 1000 \\
\hline Yunnan & 22.6 \\
\hline
\end{tabular}


TABLE III. WATER Resources IN Four Provinces AND Cities OVERVIEW IN 2015 UNIT: MILLION KILOWATTS

\begin{tabular}{|c|c|c|}
\hline province & $\begin{array}{c}\text { Water resources } \\
\text { theoretical reserves }\end{array}$ & Economically exploitable \\
\hline Sichuan & 14300 & 7611.2 \\
\hline Chongqing & 2300 & 820 \\
\hline Guizhou & 1874.5 & 1683 \\
\hline Yunnan & 10438 & 9795 \\
\hline
\end{tabular}

Finishing the four provinces and cities in the southwest of the main energy data, the southwestern region of coal and natural gas resources are more abundant, followed by hydropower resources, and finally oil resources, which is very scarce oil resources, almost entirely need to transfer from other provinces and regions. In terms of coal resources, Guizhou Province, the most abundant reserves of coal resources, forecast reserves of 240 billion tons, but Guizhou Province, almost no natural gas resources. In terms of natural gas resources, natural reserves in Sichuan Province are extremely rich, with a total resource of 718.5 billion cubic meters, and the proportion of resources is second in the country. Water resources, the theoretical reserves of water resources in Sichuan Province reached 143 million $\mathrm{kW}$, accounting for $21.2 \%$ of the country [11], second only to Tibet, is the second largest domestic water resources. In addition, Yunnan water resources are also very adequate, the territory of hydropower resources, the theoretical reserves of 104.38 million kilowatts, Technology can be developed to reach 109.13 million kilowatts, the economy can be developed to 97.95 million kilowatts, the unit area of land can be developed by the power and electricity rank first in the country.

\section{IMPACT OF SinO-BURMESE PIPELINE PROJECT ON ENERGY STRUCTURE IN SOUTHWEST CHINA}

China-Myanmar oil and gas pipeline project will have a significant impact on the energy structure in southwest China, the current energy demand situation in southwest China, and the impact on regional economic development.

\section{A. Impact of Sino-Burmese Oil Pipeline Project on Energy Structure in Southwest China}

In recent years, the economic and social development in southwest China is very fast, but in the process of maintaining economic and social development, oil resources is one of the most influential resources, Before the local petrochemical industry in Yunnan Province, the scale is small or almost no, supply of Yunnan, Chongqing and other places of refined oil from the northeast or northwest and other regions need to transport, Therefore, Yunnan has become the end of the transport of refined oil [12].

TABLE IV. ENERgy Production IN SOUthWESTERn 2015

\begin{tabular}{|l|c|c|c|l|l|}
\hline $\begin{array}{l}\text { Provin } \\
\text { ce }\end{array}$ & $\begin{array}{c}\text { raw coal } \\
\text { (Billion } \\
\text { tons) }\end{array}$ & $\begin{array}{c}\text { crude } \\
\text { (Ten } \\
\text { thousa } \\
\text { nd } \\
\text { tons) }\end{array}$ & $\begin{array}{c}\text { natural } \\
\text { gas } \\
\text { (Billion } \\
\text { cubic } \\
\text { meters) }\end{array}$ & $\begin{array}{l}\text { Power } \\
\text { generatio } \\
\mathrm{n} \\
\text { (Billion } \\
\text { kwh) }\end{array}$ & $\begin{array}{l}\text { Water } \\
\text { capacity }\end{array}$ \\
\hline $\begin{array}{l}\text { Chong } \\
\text { qing }\end{array}$ & 0.36 & - & 33.32 & 679.81 & 229.44 \\
\hline $\begin{array}{l}\text { Sichua } \\
\mathrm{n}\end{array}$ & 0.64 & 15.43 & 267.22 & 3129.59 & 2667.64 \\
\hline $\begin{array}{l}\text { Guizho } \\
\mathrm{u}\end{array}$ & 1.72 & - & 0.93 & 1814.87 & 789.23 \\
\hline $\begin{array}{l}\text { Yunna } \\
\mathrm{n}\end{array}$ & 0.52 & - & - & 2553.37 & 2177.57 \\
\hline
\end{tabular}

TABle V. OVerview of Energy Consumption in Four Provinces AND CITIES IN 2015

\begin{tabular}{|c|c|c|c|c|}
\hline Province & Coal & Crude & Natural gas & Hydropower \\
\hline Sichuan & 9288.90 & 989.56 & 170.98 & 1992.40 \\
\hline Chongqing & 6047.19 & - & 88.37 & 875.37 \\
\hline Guizhou & 12833.49 & 0.02 & 13.32 & 1174.21 \\
\hline Yunnan & 7712.85 & 0.03 & 6.34 & 1438.61 \\
\hline
\end{tabular}

(Unit: coal, oil million tons, natural gas billion cubic meters, hydropower billion kilowatt hours, Source: National Bureau of Statistics official website)

As can be seen by analyzing the energy consumption of each of four provinces and cities at present, southwest is currently the country's petrochemical industry, the more backward areas, due to lack of crude oil refining capacity, deep processing of petrochemical industry is also very backward, petrochemical products self-supply capacity is very weak, other manufacturing petrochemical products closely related to textiles, building materials, etc. are not developed.

According to the plan, the natural gas project will be completed and put into operation six branches and 13 city gas projects. Kunming East Line, Kunming West Line, Teng chong, Shidian, Mans City, Xiang yun 6 branch line project will be synchronized with the Sino-Burma natural gas pipeline production. Among them, the Kunming East Extension project through 10 counties and industrial parks [13], gas transmission scale will reach 903 million cubic meters / year; Kunming 
West Extension project through five counties and industrial parks, gas transmission scale will reach 686 million cubic meters / year.

With the completion of the Sino-Myanmar oil and gas pipeline project, China's southwestern region will gradually increase the refining capacity of 20 million tons / year, respectively, built in Yunnan and Chongqing, is expected to produce petrochemical products as shown in the table. In addition, the construction of oil refining base in Yunnan can greatly shorten the distance of crude oil transport in the country, significantly reduce transportation costs, and radiation in Sichuan, Chongqing, Guizhou, and other southwestern provinces and cities.

\section{B. The Impact of Sino-Burmese Oil Pipeline Project on the Industrial Structure in Southwest China}

For the southwestern region as a whole industry, the current four provinces and cities in the industrial structure of the secondary and tertiary industries accounted for an absolute advantage, the proportion of the secondary industry compared to the tertiary industry. The secondary industry in the main manufacturing industry, they consume large energy, and three industries on the energy consumption is relatively small, the industrial structure of the optimization and upgrading will change the energy demand structure, and industrial structure upgrade by The traditional one and two industries to the tertiary industry change. When the economy is low, economic growth will lead to increased energy consumption, and economic development to a certain extent, the energy consumption will gradually decrease. And there is a long-term reverse cointegration relationship between the energy consumption of the primary industry and the tertiary industry, and the energy consumption of the secondary industry has long-term co-integration with its industrial added value. The rising energy consumption is not caused by the primary industry and the tertiary industry, but by the development of the secondary industry.

TABLE VI. COMPARISON OF INDUSTRIAL STRUCTURE IN FOUR PROVINCES AND Cities IN SOUTHWEST CHINA IN 2016

\begin{tabular}{|c|c|c|c|c|c|c|}
\hline \multirow{2}{*}{ Area } & \multirow{2}{*}{$\begin{array}{c}\text { GDP } \\
\text { ( Billion } \\
\text { Yuan ) }\end{array}$} & \multirow{2}{*}{$\begin{array}{c}\text { GDP } \\
\text { growth } \\
\text { rate }\end{array}$} & \multirow{2}{*}{$\begin{array}{c}\text { per } \\
\text { capita } \\
\text { GDP }\end{array}$} & \multicolumn{3}{|c|}{ Industry composition $\quad(\%)$} \\
\hline & & & & $\begin{array}{l}\text { primary } \\
\text { industry }\end{array}$ & $\begin{array}{l}\text { Secondary } \\
\text { industry }\end{array}$ & $\begin{array}{l}\text { Tertiary } \\
\text { Industry }\end{array}$ \\
\hline $\begin{array}{l}\text { Coun } \\
\text { try }\end{array}$ & 74412.7 & 6.7 & 53974 & 8.56 & 39.81 & 51.63 \\
\hline $\begin{array}{l}\text { Guiz } \\
\text { hou }\end{array}$ & 1173.443 & 10.5 & 33242 & 15.74 & 39.51 & 44.75 \\
\hline $\begin{array}{l}\text { Sichu } \\
\text { an }\end{array}$ & 3268.05 & 7.7 & 39835 & 12 & 42.6 & 45.4 \\
\hline $\begin{array}{l}\text { Chon } \\
\text { gqing }\end{array}$ & 1755.88 & 10.7 & 58199 & 7.42 & 44.17 & 48.41 \\
\hline $\begin{array}{l}\text { Yunn } \\
\text { an }\end{array}$ & 1486.99 & 8.7 & 31358 & 14.8 & 39 & 46.2 \\
\hline
\end{tabular}

Based on the current status of the current industrial structure in southwest China, it is necessary to optimize the industrial structure, vigorously develop and use clean energy, especially the use of natural gas, with the help of ChinaMyanmar oil and gas pipeline project natural gas transportation, to achieve industrial structure upgrade. It is necessary to adhere to the road of new industrialization, the local governments need to adjust the province's industrial policy, strict market access, intensify efforts to eliminate backward production capacity and vigorously develop energy consumption in accordance with the national policy, in order to adjust the industrial structure, especially the structural optimization of the industrial sector Low, small pollution of the new industry.

\section{Impact of Sino-Burmese Oil Pipeline Project on Income Structure in Southwest China}

Petrochemical industry is a pillar industry of local and national economy, resource-funded technology-intensive, high industrial correlation, large economic output, the products are widely used in national economy, people's life, national defense science and technology and other fields, To promote the upgrading of related industries and stimulate economic growth plays a decisive role. Ethylene is considered the leading oil industry, marking the strength of the oil industry, Yunnan Province and the whole southwest region need to seize the favorable opportunity to develop the petrochemical industry to improve regional economic development and people's income.

TABLE VII. PER CAPITA DISPOSABLE INCOME OF FOUR PROVINCES AND CITIES IN SOUTHWEST CHINA

\begin{tabular}{|c|c|c|c|}
\hline Province & 2013 & 2014 & 2015 \\
\hline Chongqing & 16568.7 & 18351.9 & 20110.1 \\
\hline Sichuan & 14231.0 & 15749.0 & 17221.0 \\
\hline Guizhou & 11083.1 & 12371.1 & 13696.6 \\
\hline Yunnan & 12577.9 & 13772.2 & 15222.6 \\
\hline
\end{tabular}

At the same time, Yunnan Province as a country to the southwest of the opening of the "bridgehead", its future economic development will be more integrated into the neighboring countries market, Thailand, India, Vietnam, Myanmar, Laos and Cambodia will become their petrochemical products market. With the adjustment of the global manufacturing industry, these countries, light industry, textile, electrical and electronic manufacturing industry is in the rise stage, the demand for petrochemical products will continue to expand, and these countries in the future for a long period of time can not achieve the petrochemical products self-supply.

So the development of petrochemical industry in southwest region will not only promote the development of the local, but also for the real strategy to become a "bridgehead",local 
industry should seize the favorable strategic opportunities, make full use of national and government policies to upgrade the industrial structure, to provide people with better employment opportunities, and earnestly increase their income.

\section{The impact of Sino-Burmese oil pipeline project on the consumption structure in southwest China}

Relying on local resources and with the help of SinoMyanmar oil and gas pipeline strategic project favorable conditions to optimize the industrial structure, vigorously develop the southwest region of the second and tertiary industries, narrow urban and rural economic structure differences, Promote the change of lifestyle of urban and rural residents and increase the income of money. In the regional economic structure, the industrial structure determines the distribution structure, the distribution structure determines the income structure; the income structure determines the consumption structure.

The urban - rural dual structure gap of the industrial structure in the southwest region determines the urban - rural dual structure difference of the consumption structure in the southwest. Efforts to develop hydropower, mining and metallurgy as the leading industry, commerce and trade circulation, tourism-based tertiary industry, to provide employment opportunities for local urban and rural residents, encouraged farmers to leave their homes to get money income. Through the change, optimize the production structure and industrial structure to change, optimize the employment structure and income distribution structure, through the income distribution structure changes, optimization to change and optimize the consumption structure, so as to achieve fair social income distribution, reduce urban and rural income consumption differences, Social injustice, stimulate and increase the consumption needs of urban and rural residents in the southwest region, and promote the rapid and healthy development of the southwest region and social development and progress.

TABLE VIII. CONSUMPTION LEVELS OF RESIDENTS IN FOUR PROVINCES AND CITIES IN SOUTHWEST CHINA 2015

\begin{tabular}{|c|c|c|c|}
\hline Province & All residents & Citizens & Rural resident \\
\hline Country & 19308 & 27088 & 9630 \\
\hline Chongqing & 18859.7 & 25794.5 & 8336.7 \\
\hline Sichuan & 14774.0 & 20114.0 & 10038.9 \\
\hline Guizhou & 12876.3 & 20082.2 & 7866.1 \\
\hline Yunnan & 13400.5 & 20699.5 & 7819.8 \\
\hline \multicolumn{2}{|c|}{ (Source: National Bureau of Statistics official website) } \\
\hline
\end{tabular}

Through the data analysis can be seen in the four provinces and cities in the southwest of Chongqing and Sichuan Province, the level of consumption and per capita consumption expenditure than in Guizhou Province and Yunnan Province, because the income structure determines the consumption structure. So should use low-carbon high-tech transformation of traditional industries, eliminate backward production capacity. To actively use high-tech and low-carbon technology to transform traditional industries to maximize the efficiency of resource production and energy efficiency.

TABLE IX. PER CAPITA CONSUMPTION EXPENDITURE OF RESIDENTS IN FOUR PROVINCES AND FOUR PROVINCES IN SOUTHWEST CHINA

\begin{tabular}{|c|c|c|c|}
\hline Province & 2013 & 2014 & 2015 \\
\hline Chongqing & 12600.2 & 13810.6 & 15139.5 \\
\hline Sichuan & 11054.7 & 12368.4 & 13623.1 \\
\hline Guizhou & 8288.0 & 9303.4 & 10413.8 \\
\hline Yunnan & 8823.8 & 9869.5 & 11005.4 \\
\hline \multicolumn{2}{|r|}{ (Source: National Bureau of Statistics official website) }
\end{tabular}

China-Myanmar oil and gas pipeline project for the southwest of the transport of resources, to a large extent will improve the region's energy consumption structure, especially in the oil, can ease the pressure on regional oil consumption, environmental protection also have some help. The improvement of energy conditions can further affect the structure of the industry, employment situation, income structure and consumption structure.

\section{COUNTERMEASURES AND SUGGESTIONS}

\section{A. Make full use of energy supply to improve the adjustment of industrial structure}

First, optimize the industrial structure, and vigorously develop and use clean energy by means of energy input from its own resources and oil and gas pipeline projects. As far as the southwest region is concerned, the adjustment of the industrial structure, especially the structural optimization of the industrial sector, is of great responsibility. To promote industrial upgrading, to adhere to the new road to industrialization, the government should be based on the national policy adjustment of industrial policy in the province, strict market access, increase efforts to eliminate backward production capacity, vigorously develop new industries of low consumption and less pollution; on the other hand, give full play to the southwest region clean energy reserves the advantages of wind, solar and hydropower clean energy accounted for a row in the forefront of the country.

Second, Second, we should reform traditional industries with low carbon and high technology, and eliminate backward production capacity. We should actively use high-tech and low-carbon technologies to transform traditional industries so as to maximize production efficiency and energy efficiency. The government should improve the relevant policies and incentives and constraints for the elimination of backward production capacity, establish a compensation mechanism for 
rehabilitation of backward production capacity, and encourage and guide enterprises to accelerate the elimination of backward production technology, and strive to develop energy-saving technologies, innovative energy-saving way, change "high energy consumption, Out "for" low energy consumption, high output ".

\section{$B$. The use of energy prices to increase investment efforts}

First, give full play to the advantages of energy prices, and provide new impetus for investment. China-Myanmar oil and gas pipeline project is to occupy the advantages of the southwest region, greatly reducing the cost of transport of energy, so as an opportunity to give full play to the advantages of location and price advantage, accelerate the development of petrochemical industry, service industry, promote trade industry investment projects.

Second, optimize the investment environment, to create a "Prudential business", "to stay rich" good atmosphere. Continue to strengthen the construction of hard and soft environment, innovative service environment. All relevant departments should strengthen consultation and cooperation, and effectively change their style of work, further simplify procedures, improve efficiency, take the initiative to strengthen consultation and communication, and help to solve specific problems. The whole process of follow-up services for investment projects, to promote the project early landing, early production, to accelerate the investment results into a steady growth momentum.

Third, expand the field of investment, in the "strokes to attract strong" efforts. Aimed at the domestic top 500, the industry's top 50 and the central enterprises, enterprises in order to strive for breakthrough in the driving, critical, directional, strategic projects to achieve breakthroughs. Targeted to invite domestic and foreign, large and mediumsized enterprises at home and abroad, large groups to visit the city to invest, to achieve "big business", "cited real capital", while increasing the number of investment, at the same time to ensure the quality of investment.

\section{The use of energy consumption to speed up the pace of urbanization}

The population in our country is in the world the hitherto unknown scale and speed from rural to urban concentration, so that more and more people enjoy to promote the construction of new urbanization results at the same time, will also face high energy consumption of the hitherto unknown load period. China Burma oil and gas pipeline project to alleviate the shortage of energy in the short board during the process of urbanization in the southwest, but the advance in the new urbanization process, in order to fundamentally curb the excessive growth of total energy consumption, promote energy consumption patterns, from the following three aspects:

First, according to the economic and social development in different regions to determine a reasonable level of energy consumption in different areas, the implementation of differentiated planning, implement the dual control of total energy consumption and energy intensity of high energy consuming industries and excess industry, strictly control the total energy consumption growth; Second, give full consideration to the impact of the construction of the new urbanization, according to the resources environment and ecological carrying capacity of the implementation of regional differences in energy policy, and increase the cross regional transferred to transfer ability, guarantee the production integration of the city Interactive production related industries energy supply; Third, according to the level of economic development, location and resource characteristics, new urbanization and other factors, the implementation of total energy consumption control scheme, adhere to the strength of double control of total energy consumption and energy consumption principle, the provinces (city, district) of the total energy consumption of the decomposition of the implementation.

\section{Energy planning should be carried out to promote the development of related industries}

With the opening of the Sino Myanmar oil and gas pipeline, the establishment of Yunnan petrochemical base will provide ethylene, propylene and other petrochemical raw materials for the southwest. In addition to ethylene deepprocessing products, propylene, carbon, four, aromatics and other petrochemical deep-processing products demand growth potential. While the downstream petrochemical products will also be developed to maximize the China Myanmar oil pipeline oil transport capacity, the import of crude oil in Yunnan local processing and conversion, focus on the development of synthetic materials, new chemical materials and special fine chemicals and other petrochemical products.

In addition, the service industry should be vigorously developed, especially the low carbon industry based on tourism. Service sector is conducive to enhancing the structural evolution of the energy consumption slowdown effect, while the southwest region for this industry is a certain industry advantage. In the case of tourism, Yunnan alone has several world heritage sites: Old Town of Lijiang, Sanjiang, and the stone forest. Therefore, we should make full use of the advantages of tourism, on the basis of existing, and actively develop new attractions, and integration of environmental protection and low-carbon thinking, visitors can also feel and promote the concept of low-carbon tourism.

\section{CONCLUSIONS}

China-Myanmar oil and gas pipeline project is an important part of the country's four major energy strategic channel, it is of great significance to the economic development, industrial structure, energy structure, consumption structure and so on in southwest china.

It can promote the development of petrochemical industry in southwest China. As we all know, petroleum and natural gas need to be refined before they can be put into use. The economic development of a region can not be separated from petroleum, which requires petroleum refining and refining to be put into the development of the national economy. In order to supply the economic development of important cities such as southwest China, Chongqing, Chengdu and Kunming, large refineries need to be set up in this area. 
The opening of the Sino-Myanmar oil and gas pipeline can also lead to the employment of people in the relevant areas of China and Myanmar. The main unit of the construction of the Sino-Burmese pipeline project is the Petro China Pipeline Bureau, which will be recruited by the engineering staff in the relevant areas of China-Myanmar, which will provide a lot of jobs for the local staff. In July 2012, the newly established China National Petroleum Corporation Southwest Pipeline Company is to tie in with the southwest of the pipeline network construction, which can absorb more of the region and the country's relevant personnel, and to relieve employment pressure.

China-Myanmar oil and gas pipeline is an important carrier and platform for promoting exchanges and cooperation between China and Southeast Asian countries. This not only enhances China energy security, also promote the opening and exchanges between Yunnan and the southwest region, especially to strengthen the exchanges and cooperation between countries Chinese and the Greater Mekong region such as Vietnam, Laos, Thailand, Kampuchea, these countries are friendly neighbors China, can promote cooperation with ASEAN countries China more extensive. General secretary Hu Jintao put forward to build Yunnan into the "Southwest bridgehead" through the oil pipeline construction, Yunnan will become the original smelting, petroleum processing base and distribution center, Guangxi, radiation Guizhou, southwest Chongqing and other provinces, and will drive the development of the railway, highway and other related infrastructure, so it must be will expand the opening to the outside world in southwest china.

In short, the Sino-Burmese oil and gas pipeline project as an important deployment of China's energy strategy, it will not only provide important security for China's energy security, more importantly, will greatly promote China's southwestern region, Southeast Asia's economic and social development, The country has a good deal, more conducive to the long-term stability and development of Southeast Asia.

\section{ACKNOWLEDGMENT}

I am greatly indebted to my thesis supervisor, Professor Ersi Liu. Without his patient assistance and friendly encouragement, it would not be possible for me to complete this thesis. My sincere thanks should also go to all my teachers for their scholarly advice and generous help during my study in YNUFE.

\section{REFERENCES}

[1] X.M. Wang, "China's energy and gas pipeline from China and China to see the choice of energy security strategy," International Economic Cooperation, vol. 10, 2013, pp. 38-43.

[2] J. Zhang, "New dimension of energy security - written in the SinoMyanmar oil and gas pipeline across the line," China Petroleum Enterprise, vol. 6, 2013, pp. 23-25.

[3] L. Xue, "Malacca Dilemma" connotation and China's response," World Economy and Politics, vol. 10, 2010, pp. 117-123.

[4] X.F. Chen, "Myanmar reform on Sino-Burmese relations And China's Countermeasures," Southeast Asian Studies, vol. 1, 2013, pp. 43-47.

[5] L.P. Xie, "Energy consumption and urbanization, industrialization," Industrial Technology Economy,vol. 5, 2015, pp. 95-99.

[6] X. Li, "US-Burma relations to improve the impact of Southwest oil and gas import transport channel," Southeast Asia Research,vol. 2, 2013, pp. 74-79.

[7] S.P. Deng, "The Impact of Sino-Burmese Natural Gas Trade on Industrial Structure Adjustment in Yunnan Province and Its Dynamic Mechanism - Taking Yanglin Industrial Park as an Example," Yunnan University of Finance and Economics, 2015.

[8] J.C. Guo, "China's energy consumption structure changes on the impact of industrial structure research," China University of Political Science and Law, 2011.

[9] G.Z. Qin, "Yunnan energy demand analysis factors and forecast," Yunnan University of Finance and Economics, 2012.

[10] Q.J. Zhnang, Sichuan Province, "low energy consumption growth countermeasures empirical study," Sichuan University, 2007.

[11] Y. Luo, "China's regional energy consumption and economic growth," industrial structure of the empirical study. Southwest University of Finance and Economics, 2016.

[12] M.H. Li, "Southeast Asian natural gas resource country market regulation analysis," Chinese Academy of Social Sciences, 2013.

[13] J. Zhu, "Local government investment policy research," South China University of Technology, 2016. 